\title{
HUBUNGAN CARA MENGASUH OLEH ORANG TUA TERHADAP PERILAKU MEMBOLOS PELAJAR SMA
}

\author{
Oleh: \\ Novita Destiana, Gigin Ginanjar Kamil Basar, \& Sahadi Humaedi \\ e-mail: \\ destiana.novita@gmail.com
}

Tindakan membolos di kalangan pelajar bukan lah merupakan sebuah fenomena yang asing lagi. Fenomena tersebut sering terjadi baik ranah sekolah dasar maupun menengah. Berita seputar siswa yang membolos sekolah seringkali didapat baik dari media cetak ataupun media elektronik. Salah satu berita yang kabarkan dimuat di BeritaJakarta, yaitu sebanyak 33 yang terdiri dari berbagai sekolah menengah pertama (SMP), sekolah menengah atas (SMA), dan sekolah menengah kejuruan (SMK) terjaring razia yang dilakukan oleh Satpol PP Jakarta Utara pada hari Senin 2 Maret 2015. Puluhan pelajar tersebut tertangkap sedang berada di luar sekolah saat jam sekolah berlangsung. Para pelajar tersebut terjaring saat sedang berada di sejumlah pusat perbelanjaan dan juga warung internet (warnet) di wilayah Kelapa Gading.

Perilaku membolos yang dilakukan akan memberikan dampak negatif bagi murid yang melakukannya. Hukuman atau sanksi yang diberikan oleh pihak sekolah misalnya, akan merugikan diri sendiri. Pihak lain seperti sekolah mungkin tidak akan merasa dirugikan, namun orang tua murid pasti akan bekerja ekstra untuk lebih memperhatikan anaknya untuk tidak melakukan kesalahan yang sama. Atau mungkin orang tua murid yang anaknya belum pernah membolos akan melakukan tindakan preventif untuk mencegah anak mereka dari perilaku membolos sekolah. Karena kebiasaan membolos bukan hanya tanggung jawab sang anak murid, namun juga menjadi tanggung jawab orang tua murid. Dan apabila dibiarkan, maka kebiasaan membolos yang dilakukan murid sekolah ini bisa saja menimbulkan permasalahan baru. Yang mungkin tidak hanya berdampak buruk bagi diri murid itu sendiri, namun juga bagi pihak lain.

Membolos sendiri merupakan perilaku berhubungan dengan esensi dasar manusia diantaranya adalah perilaku membolos. Membolos adalah tidak masuk selama waktu pelajaran di sekolah. Teasley (dalam Jacobs \& Kristonis, 2007) mendefinisikan membolos sebagai setiap kejadian ketika seorang siswa tidak hadir sekolah. Stou (dalam Reid, 2004:59) menjelaskan bahwa perilaku membolos merupakan perilaku sebagai absen dari sekolah untuk alasan yang tidak sah. Sedangkan Reeves (2006) mendefinisikan membolos sebagai ketidakhadiran tanpa alasan selama lima kali atau lebih per semester.

Oleh karena itu penulis tertarik untuk mencari tahu apakah terdapat hubungan dari cara mengasuh yang dilakukan oleh orang tua dengan perilaku membolos pelajar SMA. Dengan mengetahui bagaimana cara mengasuh orang tua dan bagaimana kecendrungan para pelajar SMA untuk membolos, penulis akan mencari tahu apakah terdapat hubungan dari cara mengasuh yang dilakukan oleh orang tua dengan perilaku membolos pelajar sebagai anak. Dan apabila berpengaruh, maka penulis juga akan mencari tahu bagaimana kah cara mendidik yang tepat untuk mencegah 
kebiasaan membolos berdasarkan penelitian yang dilakukan.

Membolos merupakan sebuah perilaku menyimpang. Perilaku menyimpang merupakan setiap perilaku yang tidak sesuai dengan norma-norma dalam masyarakat. Sedangkan pelaku yang melakukan penyimpangan itu disebut devian (deviant). Adapun perilaku yang sesuai dengan norma dan nilai yang berlaku dalam masyarakat disebut konformitas.

Ada beberapa definisi perilaku menyimpang menurut sosiologi, antara lain menurut James Vender Zender. Perilaku menyimpang adalah perilaku yang dianggap sebagai hal tercela dan di luar batas-batas toleransi oleh sejumlah besar orang.

Selain itu menurut Bruce J Cohen, perilaku menyimpang adalah setiap perilaku yang tidak berhasil menyesuaikan diri dengan kehendak-kehendak masyarakat atau kelompok tertentu dalam masyarakat. Perilaku menyimpang menurut Robert M.Z. Lawang adalah semua tindakan yang menyimpang dari norma-norma yang berlaku dalam suatu sistem sosial dan menimbulkan usaha dari mereka yang berwenang dalam sistem itu untuk memperbaiki perilaku tersebut.

Ciri-ciri perilaku menyimpang menurut Paul B Horton penyimpangan memiliki ciri-ciri sebagai berikut.

1. Penyimpangan harus dapat didefinisikan, artinya penilaian menyimpang tidaknya suatu perilaku harus berdasar kriteria tertentu dan diketahui penyebabnya.

2. Penyimpangan bisa diterima bisa juga ditolak.

3. Penyimpangan relatif dan penyimpangan mutlak, artinya perbedaannya ditentukan oleh frekuensi dan kadar penyimpangan.

4. Penyimpangan terhadap budaya nyata ataukah budaya ideal, artinya budaya ideal adalah segenap peraturan hukum yang berlaku dalam suatu kelompok masyarakat. Antara budaya nyata dengan budaya ideal selalu terjadi kesenjangan.

5. Terdapat norma-norma penghindaran dalam penyimpangan. Norma penghindaran adalah pola perbuatan yang dilakukan orang untuk memenuhi keinginan mereka, tanpa harus menentang nilai-nilai tata kelakuan secara terbuka.

6. Penyimpangan sosial bersifat adaptif, artinya perilaku menyimpang merupakan salah satu cara untuk menyesuaikan kebudayaan dengan perubahan sosial.

Penyimpangan sebenarnya tidak selalu berarti negatif, melainkan ada yang positif. Dengan demikian, penyimpangan sosial dapat dibedakan menjadi dua macam, yaitu penyimpangan positif dan penyimpangan negatif. Penyimpangan positif merupakan penyimpangan yang terarah pada nilai-nilai sosial yang didambakan, meskipun cara yang dilakukan menyimpang dari norma yang berlaku. Contoh seorang ibu yang menjadi tukang ojek untuk menambah penghasilan keluarga. Penyimpangan negatif merupakan tindakan yang dipandang rendah, melanggar nilai-nilai sosial, dicela dan pelakunya tidak dapat ditolerir masyarakat. Contoh pembunuhan, pemerkosaan, pencurian dan sebagainya.

Sedangkan pola asuh atau pengasuhan adalah tugas membimbing, memimpin, atau mengelola. Pengasuhan yang dimaksud di sini adalah mengasuh anak (Schochib,2000, hlm.15). Menurut Darajat mengasuh anak maksudnya adalah mendidik dan memelihara anak itu, mengurus makan, minum, pakaiannya, dan keberhasilannya dalam periode yang pertama sampai dewasa. Dengan pengertian diatas dapat dipahami bahwa pengasuhan anak yang dimaksud adalah kepemimpinan, bimbingan, yang dilakukan terhadap anak berkaitan dengan kepentingan hidupnya. Pengertian pola asuh orang tua terhadap anak merupakan bentuk interaksi antara anak dan orang tua selama mengadakan 
kegiatan pengasuhan yang berarti orang tua mendidik, membimbing, dan mendisiplinkan serta melindungi anak untuk mencapai kedewasaan sesuai dengan norma-norma yang berlaku dalam lingkungan setempat dan masyarakat. Orang tua mempunyai peran yang sangat penting dalam menjaga, mengajar, mendidik, serta memberi contoh bimbingan kepada anak-anak untuk mengetahui, mengenal, mengerti, dan akhirnya dapat menerapkan tingkah laku yang baik.

Menurut Ahmad Tafsir, pola asuh berarti pendidikan, sedangkan pendidikan adalah bimbingan secara sadar oleh pendidik terhadap perkembangan jasmani dan rohani anak didik menuju terbentuknya kepribadian yang utama. Gunarso mengatakan pola asuh merupakan cara orang tua bertindak, berinteraksi, mendidik, dan membimbing anak sebagai suatu aktivitas yang melibatkan banyak perilaku tertentu secara individual maupun bersama-sama sebagai serangkaian usaha aktif untuk mengarahkan anak.

Selain pola asuh, tindakan anak juga dipengaruhi oleh faktor lain seperti sinstem sumber. Sumber adalah segala sesuatu yang dapat dimanfaatkan untuk melaksanakan keberfungsian sosial. Jenis sumber menurut Max Siporin antara lain adalah:

1. Sumber internal dan eksternal

2. Sumber offisial/ formal dan Sumber non offisial/ non formal
3. Sumber manusia dan non manusia

4. Sumber simbolik partikularistik, kongkrit universal dan pertukaran nilai

Setiap pelajar pastinya dituntut untuk mengikuti peraturan yang ditetapkan oleh pihak sekolah, baik untuk melaksanakan kewajiban ataupun menghindari larangan. Di usia pelajar yang tergolong muda, pelajar SMA khususnya, mereka sedang mengalami masa transisi. Di dunia yang mereka hadapi saat ini, akan menimbulkan berbagai macam respon yang ada di diri tiap individu. Baik yang bersifat positif, maupun yang bersifat negatif. Kenakalan menjadi fenomena yang tidak lepas dari remaja. Bentuk kenakalan remaja sebagai seorang pelajar yang paling sering ditemui adalah kebiasaan membolos.

Perilaku membolos ini perlu mendapat perhatian penuh dari berbagai pihak. Bukan saja hanya perhatian yang berasal dari pihak sekolah, melainkan juga perhatian yang berasal dari orang tua, teman maupun pemerintah. Perilaku membolos sangat merugikan dan bahkan bisa saja menjadi sumber masalah baru. Apabila hal ini terus menerus dibiarkan berlalu, maka yang bertanggung jawab atas semua ini bukan saja dari siswa itu sendiri melainkan dari pihak sekolah ataupun guru yang menjadi orang tua di sekolah juga akan ikut menangungnya. 